\title{
Holothurian assemblages before the harvest-boom era in inner reefs of Ishigaki Island, focusing on population dynamics of Iollyfish Holothuria atra Jäger, 1833
}

\author{
Shirou Nishihama ${ }^{1, *} \&$ IwaO TANITA $^{2}$ \\ ${ }^{1}$ Fisheries Technology Institute, Japan Fisheries Research and Education Agency, Nagasaki 851-2213, Japan \\ ${ }^{2}$ Yaeyama Field Station, Fisheries Technology Institute, Japan Fisheries Research and Education Agency, Okinawa 907-0451, \\ Japan
}

Received 7 October 2020; Accepted 8 December 2020 Responsible Editor: Satoshi Wada

doi: $10.3800 /$ pbr. 16.165

\begin{abstract}
Distribution and abundance of holothurians before the boom of fisheries in the 1990s were analyzed in relation to types of bottom sediment and biomes in inner reefs of Ishigaki Island, Okinawa, Japan. The data had been collected continuously over three years at Yoshihara and once at three other sites. Fifteen species were found, among which the dominant Holothuria atra and Stichopus chloronotus were abundant on bottoms with sand and seagrass, and those with sand and coral cobbles, respectively. The continuous survey at Yoshihara revealed that the overall density of $H$. atra was 2 to 3 ind. $\mathrm{m}^{-2}$, which was the highest among values reported previously, and spatial-temporal distribution of $H$. atra was almost stable throughout the research period, but the distribution of St. chloronotus fluctuated irregularly. The density of $H$. atra fluctuated seasonally (high in winter and low in summer) and was correlated negatively with air temperature and irradiation, and positively with cloud cover. The body length of $H$. atra became longer in summer and shorter in winter. The frequency of asexual reproduction (fission) was estimated at less than $1 \%$ of annual recruitment, and the growth rate was estimated to be low ( $\mathrm{K}=0.0845$ in von Bertalanffy equation). The high density and slow growth suggested that the $H$. atra population had reached carrying capacity at Yoshihara. The sandcoated ratio of $H$. atra was positively correlated with wind speed, however, no trend was found with the spatial-temporal variation in the density and distribution of the sand-coated individuals.
\end{abstract}

Key words: Distribution, Holothurians, Population, Species composition, Unfished period

\section{Introduction}

Tropical holothurians have been important historically as food, and recently as folk remedies and cosmetic products. They are fished and consumed around South East Asia and China as bêche-de-mer (trepang). In coastal ecosystems, holothurians play ecological roles as bioturbators of sediment to enhance recycling of organic elements (Birkeland 1988, Uthicke 2001a, Purcell et al. 2016a). They are also prey in coral reef food webs (Bourjon \& Vasquez 2016, Francour 1997), and hosts of various symbionts and parasites (Purcell et al. 2016a, Hamel et al. 2017, Mueller 2017). Because of the dramatic increase in demand since the late 20th century (Conand \& Byrne

*Corresponding author: Shirou Nishihama; E-mail, chiton@fra.affrc. go.jp
1993, Toral-Granda et al. 2008, Conand 2018), holothurian fisheries have been established around the world, causing a marked decrease in resources (Friedman et al. 2011, Purcell et al. 2013). To maintain resources sustainably, it is necessary to obtain biological information about distribution, reproduction, population characteristics and meta-population structure (Roff \& Zacharias 2011). However, such ecological data are limited in many areas of the world. One of the reasons for this is that the natural populations of the holothurians have been overexploited by fisheries already (Hasan 2005, 2019, Anderson et al. 2011), which makes it difficult to survey the ecology of unaffected populations (but see Eriksson et al. 2012, Koike et al. 2015, Lampe 2013, Lampe-Ramdoo et al. 2014).

Scientific investigations of holothurians in Japan have been almost exclusively conducted on Apostichopus japonicus (Selenka, 1867) in temperate/subarctic areas 
(Choe 1963, Akamine 2004, 2015), especially from the aspect of aquaculture. There have been few ecological studies on the tropical Indo-Pacific holothurian fauna in the Amami Islands (Kagoshima Prefecture) and Ryukyu Islands (Okinawa Prefecture), southwestern Japan (but see Uehara 1991, Tanita \& Yamada 2019, Yamana et al. 2020), despite their importance as local fishery resources. Apart from commercial importance, Nishihira et al. (1978) reported preliminary studies on intertidal population of Polycheira rufescens (Brandt, 1835) in Okinawa Island, suggesting several aspects and problems in ecological research of coral reef holothurians. Because of resource depletion caused by overexploitation after 2000 throughout almost all of these Islands, there is a growing demand to understand the population ecology of the holothurians before the exploitation period.

In this paper, we report the pre-fished condition of holothurian assemblages during the late 1990s in Ishigaki Island, located in the southwestern area of the Ryukyu Islands. We focused on the spatial relationships between the bottom characteristics of the habitats and distributions of major holothurians, namely Holothuria atra Jäger, 1833, Holothuria leucospilota Brandt, 1835 and Stichopus chloronotus Brandt, 1835 in reef flats, and pools of fringing reefs. The seasonal distribution patterns and body length compositions of the most dominant species were investigated. Additionally, H. atra is known to possess characteristic ecology, such as asexual fission and the attachment of sand particles on the body surface, which are regarded as adaptations to shallow coastal environments. Asexual fission is a major way of reproduction for the small morphotype of $H$. atra, mainly living in shallow habitats (Bonham \& Held 1963). This plays a role in maintaining the population density but also limits their body sizes, resulting in a decrease in the capacity for sexual reproduction (i.e., holding less gonads) (Chao et al. 1993, 1994). In contrast, the large morphotype living in deeper habitats never conducts fission (Chao et al. 1993). Several factors are suggested as the mechanisms to promote asexual fission, such as mortality, habitat stability, optimum individual size, food availability and larval supply (Uthicke 2001b), but these are not fully verified (Lee et al. 2008). It is suggested also that asexual fission occurs during summer and winter in the northern and southern hemispheres, respectively. This difference in seasonality between the hemispheres is inferred to be related to daily low tides (Chao et al. 1993). However, there are a limited number of reports on seasonal patterns of asexual fission, especially in the northern hemisphere (Wada 1992, Chao et al. 1993, 1994, Wakabayashi \& Wada 2010). Thus, it is not fully understood how holothurians determine the frequency of fission in response to environments.

The behavior of coating the body surface with sand particles may be an ecological adaptation, such as (1) reflecting sunshine with light-colored sand to keep the body temperature low, (2) protection from ultraviolet radiation or (3) anti-predation camouflage (Bonham \& Held 1963). Bonham \& Held (1963) compared the inner body temperature of both types of $\mathrm{H}$. atra in tide pools, but the difference was very small; the body temperature of non-coated individuals were $0.25^{\circ} \mathrm{C}$ higher in average than the neighboring coated ones. This raises questions as to whether sand-coating behavior is arbitrary or is necessary for the survivorship and dominance of $H$. atra on a population scale under certain environments, or whether there are mechanisms controlling the frequency of sand-coated individuals. However, the long-term trends of the sand-coated ratio of $H$. atra have not yet been investigated. Based on three years of observations, we explore the environmental factors that determined the frequency of sand-coating behavior of $H$. atra and discuss its ecological meaning.

\section{Materials and Methods}

\section{Field observations}

The distribution patterns of holothurians were surveyed at four sites on Ishigaki Island during the low tide of spring tides: Yonehara and Yoshihara on the northern coast, Kan-non-zaki at the southwestern point, and Shiraho on the southeastern coast (Fig. 1). The surveys were conducted once at Shiraho (29 Nov. 1996), Kan-non-zaki (27 Jan. 1997) and Yonehara (7 Feb. 1997), while at Yoshihara surveys were done continuously from 24 April 1997 to 3 March 2000 at intervals of two to four months to investigate seasonal variations. All of these coasts are open to the ocean and commonly have fringing reef structures from the shore to seaward, namely, sandy beaches, shore reefs, shallow shore pools, reef flats (usually dominated by seagrasses), mid-lagoon (1-2 $\mathrm{m}$ deep) with micro-atolls, back reef and fore reef. At the four sites, we set line transects (50 to $450 \mathrm{~m}$ long depending on the shore type and area) from the low tide edge of the shores to the reef edge. We set two transects at Yonehara, three at Kan-non-zaki, and one at Yoshihara and Shiraho. Four $1 \times 1 \mathrm{~m}$ quadrats were randomly placed at intervals of $25 \mathrm{~m}$ from the shore (12.5 $\mathrm{m}$ in the latter half of the study period after December 1998 at Yoshihara), and the species and number of holothurians inside the quadrats were recorded. Simultaneously, habitat types in the quadrats were categorized as follows: Bare Rock (BR); limestone with no conspicuous sediments or biomes covering the surface; Seagrass (SG), dominated by seagrasses mainly Thalassia hemprichii (Ehrenberg) Ascherson and Halophila ovalis (R. Brown) J.D. Hooker; Sandy Bottom (S), bottom covered by coral sand without other types of sediments or biomes; Coral Cobbles (CC) and Coral Rubble (CR), dominated by dead coral stones larger than and smaller than a fist, respectively; Sargassasea (SS), dominated by brown algae mainly Turbinaria ornata (Turner) J. Agardh; Live Coral (LC), dominated by living hermatypic corals; and Soft Coral (SC), dominated by soft corals mainly Alcyonacea. Ad- 


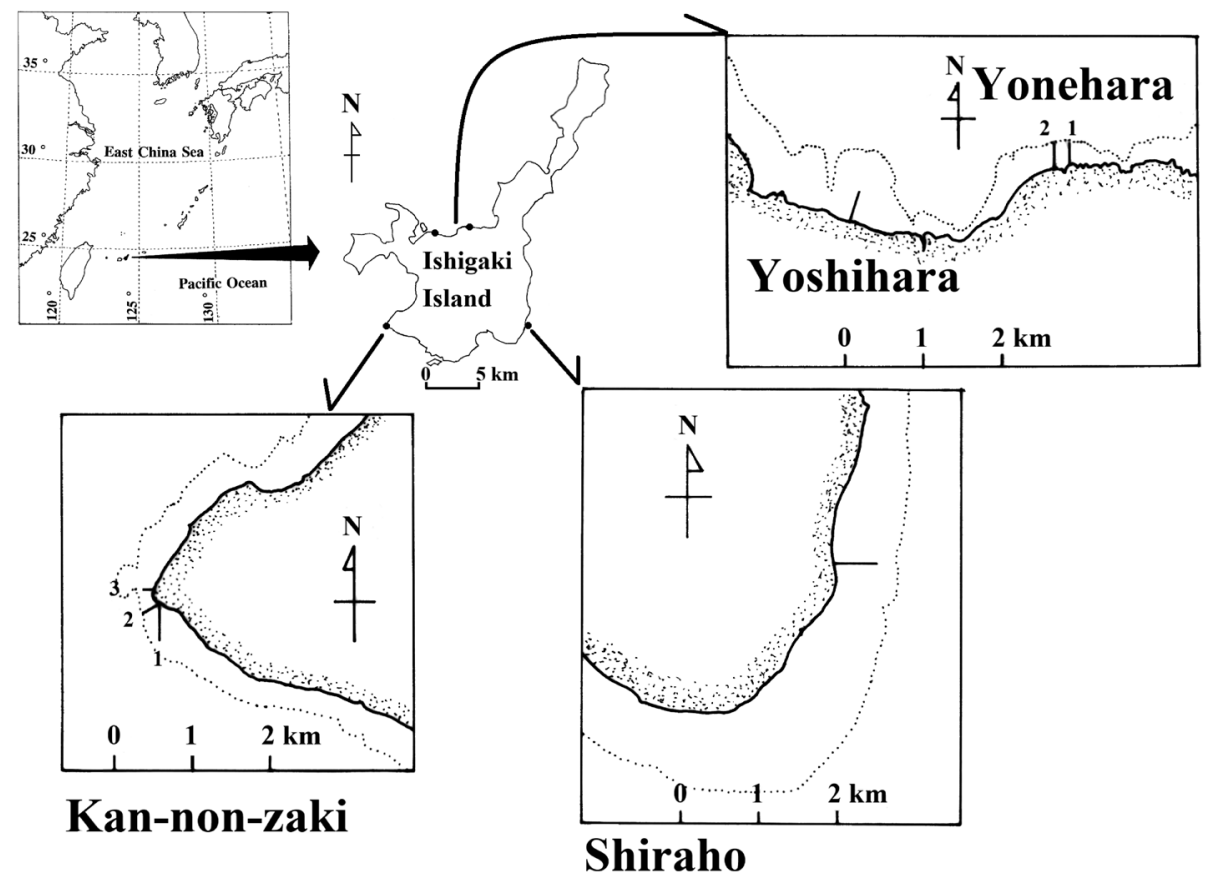

Fig. 1. Location of sites where the spatial distribution of holothurians was surveyed around Ishigaki Island. On the coastal reef of Yoshihara one $250 \mathrm{~m}$ transect was set, and on Shiraho one $450 \mathrm{~m}$ transect was set. Two transects were set at Yonehara; No. 1 was $250 \mathrm{~m}$ and No. 2 was $125 \mathrm{~m}$ long. The length of three transects at Kan-non-zaki were: $450 \mathrm{~m}$ (No. 1), $200 \mathrm{~m}$ (No. 2) and $50 \mathrm{~m}$ (No. 3). The length of the transects was determined by taking into consideration the distribution range of holothurians at each site.

ditionally, non-coral cobbles, pebbles, and other macroalgal habitats were identified. Holothurians observed outside the quadrats were also recorded non-quantitatively. In the case of the S habitat category, the presence/absence of burrowing species was confirmed by groping underneath the sand. Along the transect, the number of sand-coated and non-coated $H$. atra was recorded. There were different levels of sand-coating including the typical condition that the whole surface except around the dorsal podia was coated to various levels. All levels were counted as sandcoated, while completely naked individuals were counted as non-coated. The body length of $H$. atra was surveyed in a dense population observed at the seagrass-dominated point, $100 \mathrm{~m}$ from the shore at Yoshihara. To obtain a sufficient amount of data, fifteen to twenty $1 \times 1 \mathrm{~m}$ quadrats were placed randomly, and the body length of $H$. atra individuals inside the quadrats was measured to the nearest $0.5 \mathrm{~cm}$, by carefully placing a flexible measuring tape above the animals to avoid body contraction. We also recorded individuals of $H$. atra and St. chloronotus which were during or after fission, judged by constricted body or lack of either mouth or anus with an obviously shorter body length, respectively (Chao et al. 1993).

\section{Analysis of distribution patterns of dominant species and sand-coating of $\boldsymbol{H}$. atra}

To analyze the distribution patterns in relation to habitat types of the abundant species $H$. atra, St. chloronotus, and $H$. leucospilota, weighted mean densities were calculated for the habitat types where they were distributed, using the transect data from all 4 sites. In this analysis, we used data from December 1998 in Yoshihara for comparison with the other three sites, where sampling was conducted during winter, to keep similar seasonal factors. The distribution of $H$. atra and St. chloronotus were checked for spatial autocorrelation using Moran's I (Gittleman \& Kot 1990) calculated using "Moran.I" function of package "ape" (Paradis 2019) in R software ver. 3.6.2 (R Development Core Team). To investigate the factors involved in the distribution and abundance of holothurians, Spearman's rank correlation analysis was conducted between the densities and mean body size, Moran's I of H. atra and St. chloronotus, the sand-coated ratio of $H$. atra and the weather variables including daily maximum, mean and minimum air temperature, daily mean precipitation, daily irradiance time, daily total irradiance, daily cloud cover and daily mean wind speed. The weather data were obtained from the AMEDAS (Automated Meteorological Data Acquisition System) data sets of the Ishigaki Island Local Meteorological Observatory. To analyze the seasonal variation of mean body lengths of $H$. atra in Yoshihara, non-parametric multiple comparison (Steel-Dwass test) was conducted among observation days using the "pSDCFlig" function with asymptotic method in the package "NSM3" (Schneider et al. 2018) after the Kruskal-Wallis test ("kruskal.test" function) in $\mathrm{R}$.

\section{Growth estimation from body length composition of H. atra}

Using the body length composition of $H$. atra, the 
growth rate, and maximum length were estimated by Electronic LEngth Frequency ANalysis with simulated annealing ("ELEFAN_SA" function) in the "TropFishR" package (Mildenberger et al. 2017) in R. In the ELEFAN_SA analysis, we set the variability range of growth oscillation (C) from 0 to 4 , where $\mathrm{C}=0$ : constant growth, $0<\mathrm{C}<1$ : seasonally variable growth, $\mathrm{C}=1$ : seasonally no growth, $1<\mathrm{C}<4$ : seasonal shrinkage (degrowth). A value of $\mathrm{C}$ greater than 4 was not assumed, as it gave inaccurate results in preliminary trials with fixed C values using "ELEFAN" function, with too large seasonal variability of growth.

\section{Results}

\section{Holothurian composition at the four sites}

In total, 15 species were observed from four sites, among which eight species were quantitatively evaluated by transect surveys, namely, $H$. atra, $H$. leucospilota, Holothuria edulis Lesson, 1830, Actinopyga echinites (Jäger, 1833), St. chloronotus, Stichopus cf. horrens Selenka, 1867, Bohadschia vitiensis (Semper, 1868) and Synapta maculata (Chamisso \& Eysenhardt, 1821) (Table 1, Fig. 2). Nine species were observed at Shiraho, among which only H. atra and St. chloronotus were counted quantitatively. At Kan-non-zaki, six species were recorded along the transect and Holothuria whitmaei Bell, 1887 was recorded outside the transect. At Yonehara, six species were recorded quantitatively; Actinopyga mauritiana (Quoy \& Gaimard, 1833) was found in cryptic habitats, which our quadrat could not capture. Greenfish St. chloronotus dominated the transect at Yonehara but were abundant only on the reef crest and fore reef at Kan-non-zaki. Along the short transect at Kan-non-zaki where the intertidal reef flat was narrow, $H$. leucospilota dominated, however, its habitat range was restricted. On the reef flat and pools at Yoshihara, $H$. atra dominated, with distribution centered around 50 to $150 \mathrm{~m}$ from the shore where seagrass covered the sandy bottom; St. chloronotus was the next most common species but was found more to seaward. Overall, the high-density species were H. atra (12.5 to 340.6 ind. $100 \mathrm{~m}^{-2}$ ), St. chloronotus ( 28.1 to 195.3 ind. $100 \mathrm{~m}^{-2}$ ), and H. leucospirota (1.6 to 14.6 ind. $100 \mathrm{~m}^{-2}$ ). Other species ranged from 1.0 to 5.6 ind. $100 \mathrm{~m}^{-2}$ in density (Table 1 ).

The weighted mean densities of each bottom type showed that $H$. atra was most abundant on SG beds, followed by S, and then on CR (Fig. 3); St. chloronotus was more abundant on $\mathrm{S}$ and $\mathrm{CR}$ bottoms; however, it was also found on SS, LC, and BR bottoms; H. leucospilota, which was conspicuous at Kan-non-zaki, preferred BR since they were often observed inserting their posterior end under stable coral rocks or into crevices of limestone as anchors.

\section{Temporal variations in distribution and population structure of dominant species at Yoshihara}

The continuous transect surveys at Yoshihara showed
Table 1. List and density $100 \mathrm{~m}^{-2}$ of recognised holothurian species.

\begin{tabular}{|c|c|c|c|c|}
\hline & Yoshihara & Yonehara & Kan-non-zaki & Shiraho \\
\hline Actinopyga echinites & & 1.6 & 2.1 & \\
\hline A. mauritiana & & + & & \\
\hline Bohadschia argus & & & & + \\
\hline B. vitiensis & 5.6 & & & \\
\hline Holothuria atra & 229.6 & 50.0 & 12.5 & 340.6 \\
\hline H. edulis & & & 2.1 & + \\
\hline H. hilla & & & & + \\
\hline H. impatiens & & & & + \\
\hline H. leucospilota & & 1.6 & 14.6 & + \\
\hline H. whitmaei & & & + & \\
\hline Stichopus chloronotus & 124.1 & 195.3 & 42.7 & 28.1 \\
\hline St. herrmanni & & & & + \\
\hline St. cf. horrens & & & 1.0 & \\
\hline St. sp. & & & & + \\
\hline Synapta maculata & & 4.7 & & \\
\hline
\end{tabular}

The figure + means that these species were found near the transects but could not be captured by quadrats.

that the density of $H$. atra was nearly stable over the three years survey (Fig. 4a). The overall density of $H$. atra fluctuated between 169 and 353 ind. $100 \mathrm{~m}^{-2}$. The density of non-sand-coated $H$. atra was always lower than 58 ind. $100 \mathrm{~m}^{-2}$, with no conspicuous trend (Fig. 4a). The density of St. chloronotus was less than 150 ind. $100 \mathrm{~m}^{-2}$ and showed decreasing trend during the survey $(p<0.05)$ (Fig. 4b). The spatial distribution of $H$. atra along the permanent transect in Yoshihara showed a stable pattern throughout the survey period, with density peaks around 50 to $150 \mathrm{~m}$ from the sandy beach (Fig. 5a). This area was covered by seagrasses $T$. hemprichii and Ha. ovalis in all seasons. On the other hand, St. chloronotus was often found more to seaward than $H$. atra, but it was also found in very nearshore points and their density peaks were unstable with no seasonal pattern (Fig. 5b).

The body length of $H$. atra measured in Yoshihara ranged from 2 to $26 \mathrm{~cm}$, and they tended to be longer from spring to autumn (April to October) and shorter from autumn to early spring (September to March) (Fig. 6). From April to August 1997, the average body length increased $(p<0.05)$ and then remained almost unchanged until April 1998. It increased again from April to October $1998(p<0.05)$ and then decreased in December 1998 $(p<0.05)$. From December 1998 to July 1999, the length increased again $(p<0.05)$ and decreased from September 1999 to January $2000(p<0.05)$. The mode of the body length histograms of $H$. atra (Fig. A1) showed considerable seasonal fluctuation, moving from 8 to $10 \mathrm{~cm}$ in April and June 1997 toward 12 to $14 \mathrm{~cm}$ in January 1998. Shorter individuals $(<10 \mathrm{~cm})$ lengthened with the mode at 10 to $12 \mathrm{~mm}$ in the following summer, and the mode moved toward the longer class until October 1998. It followed a bimodal pattern in December 1998, having modes at 6 to 


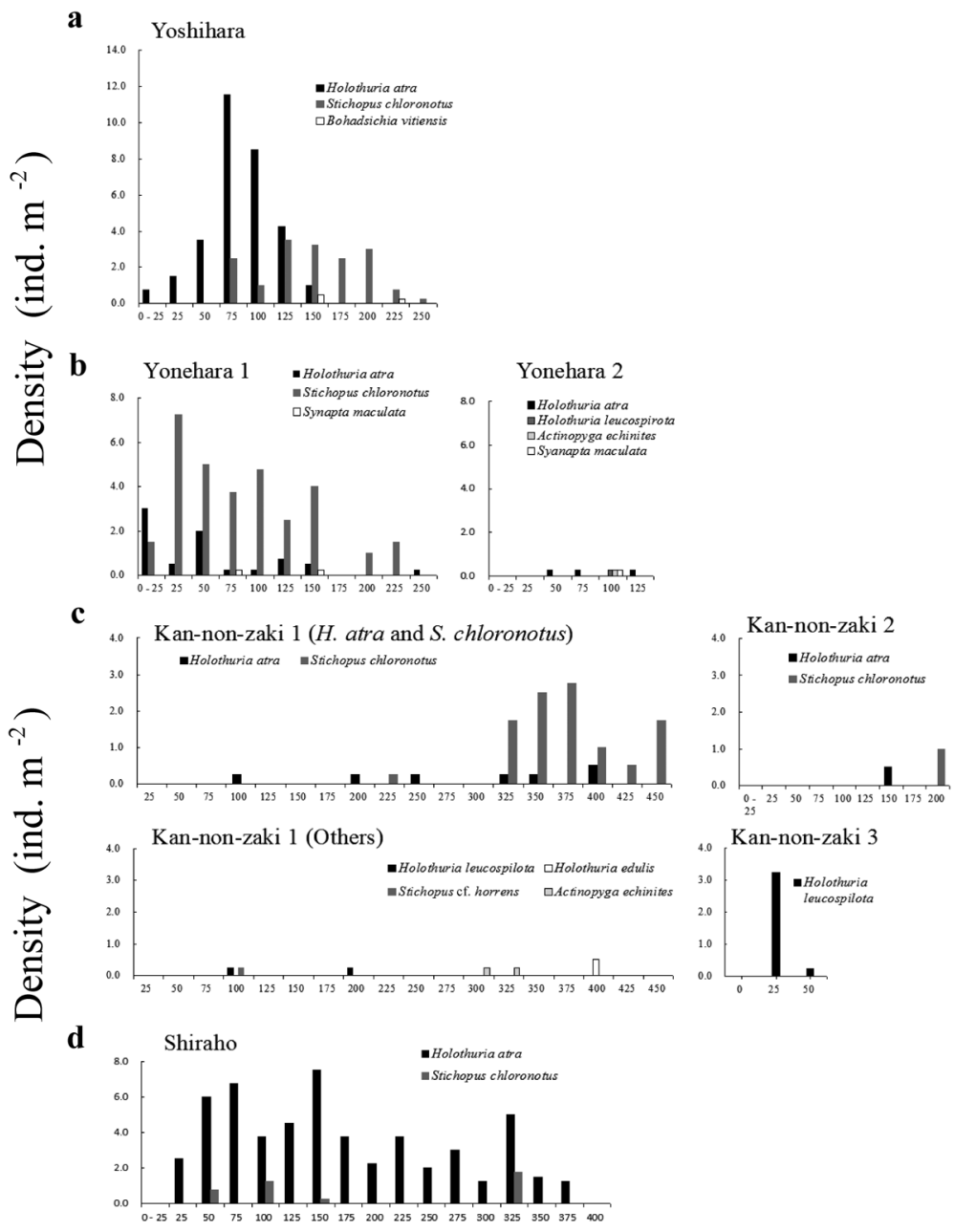

Distance from the landward edge of the beach (m)

Fig. 2. Distribution and densities of dominant holothurians along the transects at the four sites from November 1996 to April 1997. Along Transect 1 at Kan-non-zaki, the two dominant species (Holothuria atra and Stichopus chloronotus) and the other species (H. leucospirota, H. edulis, St. cf. horrens and Actinopyga echinites) are exhibited separately to avoid confusion.

$8 \mathrm{~cm}$ and 10 to $12 \mathrm{~cm}$. A similar bimodal pattern appeared again in January 2000. The growth rate ( $\mathrm{K}$ in von Bertalanffy equation), and maximum age body length of $H$. atra were calculated as 0.0845 , and $37.3 \mathrm{~cm}$, respectively, by cohort analysis. The calculation of $\mathrm{C}$ as 2.40 showed that there was seasonal shrinkage of body length.

Throughout our survey, only one $H$. atra preceding asexual fission was found by quantitative random sampling at Yoshihara. This fissiparous individual found in December 1998 had a shorter posterior part $(5 \mathrm{~cm})$ and longer anterior $(8 \mathrm{~cm})$ parts, twisting and being connected by tuberous tissue. One individual $(11 \mathrm{~cm})$ after fission was observed in May 1999 for H. atra, and one $(9 \mathrm{~cm})$ in January 2000 for St. chloronotus. Apart from line transect and quadrats, fission was not rare for $H$. atra (but only 4 examples were recorded as photos: Nishihama per. obs.), mainly being found in winter to early spring.

Spearman's correlation analysis (Table 2) revealed that the temporal variation in the density of $H$. atra was nega- tively correlated with daily maximum, mean and minimum temperature, daily irradiance time and daily total irradiance, and positively correlated with cloud cover $(p<0.05)$. A positive correlation was found between Moran's I of $H$. atra and daily mean wind speed $(p<0.05)$. The ratio of sand-coated $H$. atra also had a positive correlation with daily mean wind speed $(p<0.05)$. The body length of $H$. atra showed a negative significant correlation with its own density and was significantly and positively correlated with maximum air temperature $(p<0.05)$.

\section{Discussion}

\section{Densities and distribution patterns}

Few holothurian studies have been done in the Ryukyu Islands following the taxonomic works in the early 20th century (e.g., Mitsukuri 1912, Ohshima 1935), except for some pictorial guidebooks (e.g., Imaoka 1995). Nidshihi- 


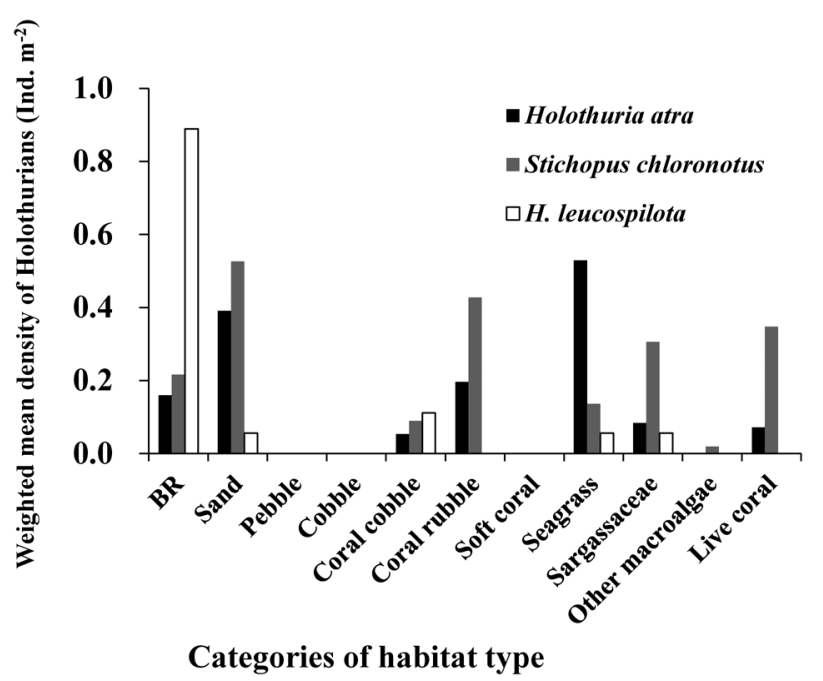

Fig. 3. Weighted mean densities of dominant holothurian species on each habitat type. All data from surveyed sites from November 1996 to February 1997 at Shiraho, Kan-non-zaki and Yonehara, and that of December 1998 at Yoshihara were used for analysis.

ra et al. (1978) reported preliminary observations of $P$. rufescens in Okinawa and suggested some technical possibilities and problems in research of holothurians in coral reefs. Recently, Tanita \& Yamada (2019) investigated the distribution of dominant sea cucumbers on Ishigaki Island in relation to sediment organic content, and Yamana et al. (2020) reported the distribution pattern of sea cucumbers in the semi-enclosed waters of the Amami Islands. However, Tanita \& Yamada (2019) worked in 2016 and Yamana et al. (2020) in 2018, following the overharvesting of holothurians in their study sites. Our study is the quantitative description of the holothurian assemblages during the pre-harvest era (before 2000) in shallow reef flats and pools around Ishigaki Island, which was considered to preserve the original characteristics of this faunal group in the Nansei Islands (including the Amami Islands and the Ryukyu Islands). The species composition of holothurians in Ishigaki Island followed a pattern common to the IndoWest Pacific (e.g. Chao \& Chang 1989, Toral-Granda et al. 2008, Purcell et al. 2012); H. atra, St. chloronotus and $H$. leucospilota were dominant in the reef flat and lagoon environments. Some species were not evaluated by our method. For example, A. mauritiana was common on the fore reef at Yonehara and Shiraho, but was not recorded in our study, because they are hidden under overhung massive corals or in reef crevices during the day (Graham \& Battaglene 2004).

Compared with other studies around the Indo-West Pacific region, the densities of the major species on Ishigaki Island were very high. For example, $H$. atra densities were 12 to 340 ind. $100 \mathrm{~m}^{-2}$ (Fig. 5), as against the other reported values even in unfished areas of 17 to 143 ind. $100 \mathrm{~m}^{-2}$ in southern India (Asha et al. 2015), 14.7
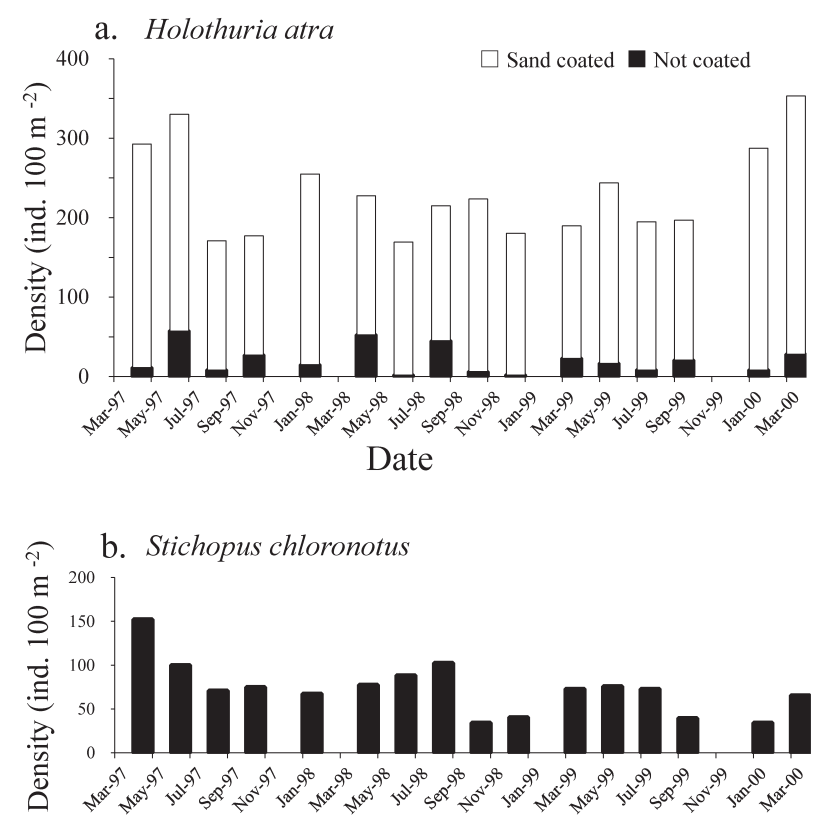

Date

Fig. 4. Temporal variation of abundance of a) Holothuria atra and b) Stichopus chloronotus. In the case of $H$. atra, densities of non-sand-coated and sand-coated individuals are expressed by black bars and white bars, respectively.

to 75.4 ind. $100 \mathrm{~m}^{-2}$ in Pompei (Bourgoin \& Edward 2005) and 4.24 to 38.73 ind. $100 \mathrm{~m}^{-2}$ in Mauritius (Lampe 2013, Lampe-Ramdoo et al. 2014). The estimated density of $H$. atra at Ishigaki Island during the pre-harvest era was equivalent to the very high records at Eniwetok Atoll in Marshal Islands, of 24 to 406 ind. $100 \mathrm{~m}^{-2}$ (Webb et al. 1977). The very high densities of St. chloronotus, at 28.1 to 124.1 ind. $100 \mathrm{~m}^{-2}$ (Fig. 5) in this study, were comparable with the highest levels elsewhere (Uthicke 1994, 2001b, Lampe 2013, Lampe-Ramdoo et al. 2014). Within Ishigaki Is., the abundance of $H$. atra obtained at Yoshihara and St. chloronotus at Yonehara were higher than those at the other sites (Fig. 2). Therefore, it is assumed that the densities of dominant species even in the pre-harvest period exhibited site-specific variation. In 2017, Tanita \& Yamada (2019) surveyed holothurians at the same site (Yonehara) and an adjacent site (Yamabare), and revealed that the density of H. atra was 12 ind. $100 \mathrm{~m}^{-2}$ and St. chloronotus was 34 ind. $100 \mathrm{~m}^{-2}$. Although their method was not the same as ours, it can be assumed that the abundance of these species on the north coast of Ishigaki Island decreased over the 17 years between the two studies.

There was a significant variety of habitat preferences among H. atra, St. chloronotus and H. leucospilota, indicated by the weighted mean densities in relation to the habitat types. For example, H. atra preferred SG beds and $\mathrm{S}$, as well as CR and BR, while St. chloronotus appeared on almost all the habitat types (Fig. 3). However, the mean density of St. chloronotus was relatively low in SG beds where $H$. atra was abundant. Although it is unclear what 


\section{a. Holothuria atra}

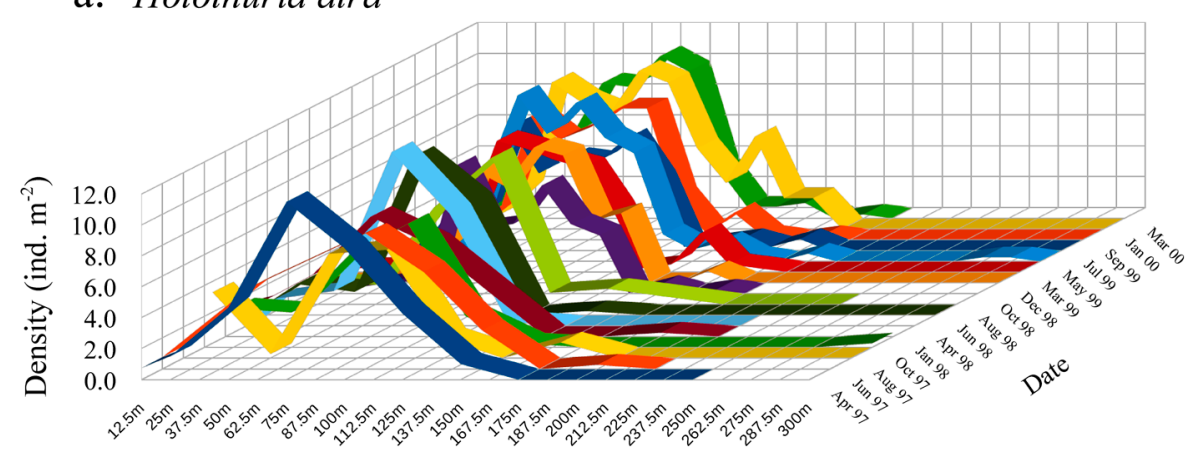

Distance from the edge of the beach

\section{b. Stichopus chloronotus}

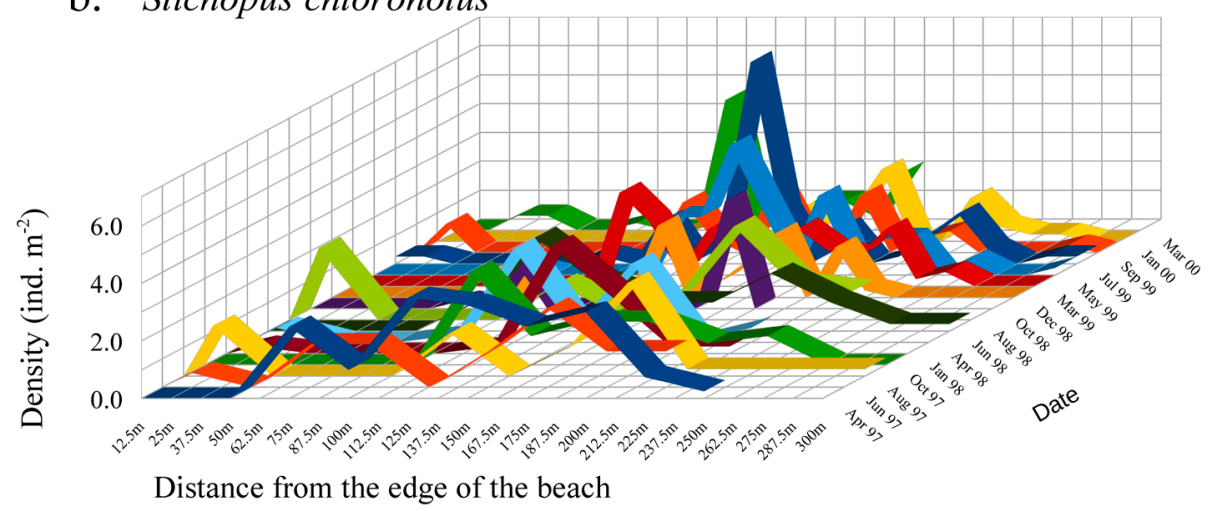

Fig. 5. Temporal variations in density of a) Holothuria atra and b) Stichopus chloronotus along the fixed transect at Yoshihara. As described in the text, four quadrats were set at the surveyed points, however, the standard error of the mean is not shown here for clarity.

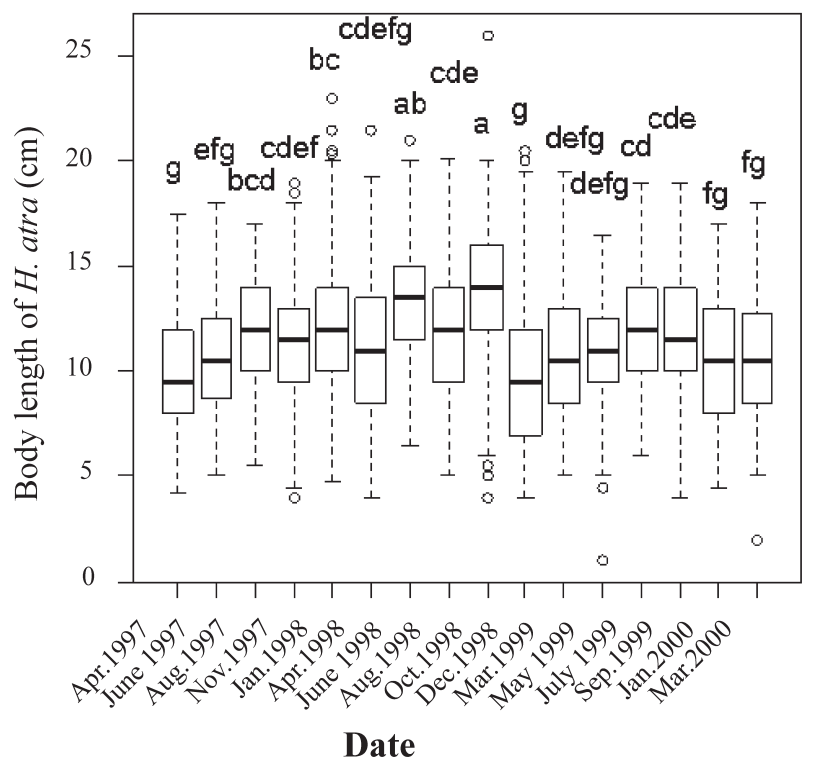

Fig. 6. Box-whisker plot of the body length of Holothuria atra and their temporal variation on seagrass-dominated reef flat at Yoshihara. Letters above each plot indicate the results of Steel-Dwass test of multiple comparison. If same letters are shown among the plots, there are no significant difference among the body length of $H$. atra $(p>0.05)$, and the pairs with no common letters indicate a significant difference $(p<0.05)$. kind of environmental factors determine the habitat difference, it might come from feeding selectivity shown between these two species or sediment particle size and the amount of microbial organisms (Moriarty 1982, Massin \& Doumen 1986, Uthicke 1999, 2001a, Uthicke \& Karez 1999). We found that $H$. leucospilota preferred BR, often inserting their posterior end in the stable rocks as anchors, as reported by Bonham \& Held (1963). This defensive behavior from predators seems to be the primary factor for the habitat selection of this species, although that they are also known to utilize SG habitats (Setyastuti et al. 2018, Komala et al. 2019, Susetya et al. 2019).

\section{Seasonal population dynamics of $\mathrm{H}$. atra}

During winter, the density of $\mathrm{H}$. atra increased and their body length decreased (Figs. 4 and 6). The results of the correlation analysis supported this pattern; the density of $H$. atra was negatively correlated with daily mean temperature and daily irradiance, and positively correlated with cloud cover $(p<0.05)$, consistent with the cloudy winter weather in Okinawa. The mean body length of $H$. atra was positively and negatively correlated with daily mean air temperature and its density, respectively $(p<0.05)$. To explain this seasonal pattern of body length and density, 


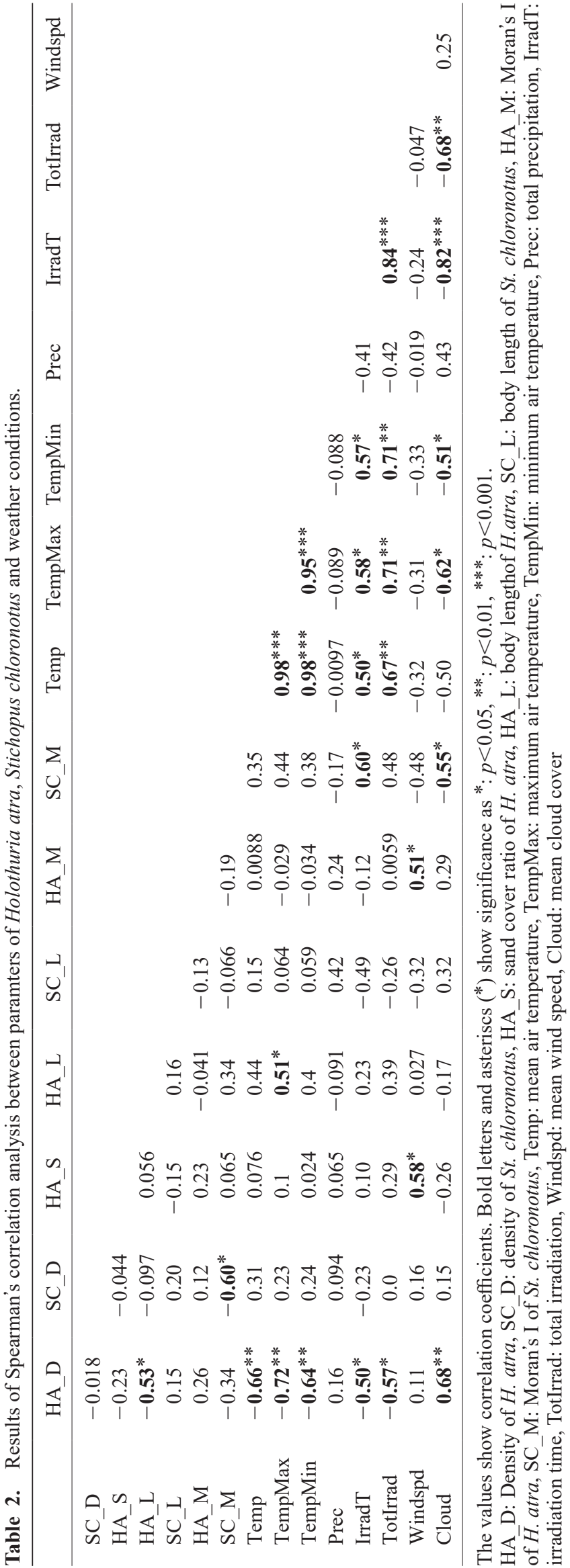

we considered that the following three possibilities might increase the number of small individuals: (1) sexual reproduction, (2) asexual fission and (3) seasonal growth and shrinkage of individuals.

Asexual fission is an important reproductive method to sustain population densities of $H$. atra (Ebert 1978, Harriott 1982, Chao et al. 1994, Uthicke 2001b), especially in environments where recruitment from sexual reproduction is limited (Uthicke et al. 1998). In our observation, individuals during or after fission were mainly observed from winter to early spring. Therefore, asexual fission was one of the potential factors explaining the increase in density with a decrease in the body length of $H$. atra during winter (Figs. 4 and 6). However, the frequency of asexual fission in this study was low; one individual was observed during fission on 4th December 1998 (two recruits in 156 ind.) and one individual after fission on 17th May 1999 (one recruit in 135 ind.), contributing 1.3\% and $0.74 \%$ in the total population, respectively. Across the 16 surveys, the frequency was $0.13 \%$, which is the lowest among previously reported values for $H$. atra (Chao et al. 1993, 1994, Conand 1996, Lee et al. 2008, Thorne et al. 2013). The period for complete recovery of the tentacles or anus after fission was 7 to 11 weeks for $H$. atra (Purwati et al. 2009), although the wounds from fission healed and closed in 2 days to 3 weeks (Laxminarayana 2006, Purwati et al. 2009). Therefore, even if asexual fission continued all year round at a frequency of $0.13 \%$ of the total population and each recovered in 2 months, asexual fission would contribute to only $0.78 \%$ of the total population (as 6 cycles of fission occur) in a year. Thus, asexual fission was considered a minor factor for population dynamics, and recruitment was most probably from sexual reproduction at Yoshihara.

The seasonality of the observed asexual fission of $H$. atra in this study was winter to spring both inside and outside the transect lines, although the number of fissions was low. This was inconsistent with existing studies that the highest fission activity occurred during summer in the northern hemisphere and during winter in the southern hemisphere for Indo-Pacific species (Chao et al. 1993, Dolmatov 2014). It has been argued that fission is related to different timing of low tides and that stress from solar radiation during low tides might trigger asexual fission; the low tide of spring tides in summer occurs diurnally in the northern hemisphere and nocturnally in the southern hemisphere (Chao et al. 1993, Dolmatov 2014). However, the example in Dolmatov (2014) in the northern hemisphere H. atra was only that of Chao et al. $(1993,1994)$ on the southern coast of Taiwan, $450 \mathrm{~km}$ southwest of our survey point. For non-commercial Indo-Pacific species in Japan, Wada (1992) suggested possibility of winter fission of $P$. rufescens, and Wakabayashi \& Wada (2010) reported that of Patinapta ooplax (von Marenzeller, 1882). Therefore, our results imply that the seasonality of asexual fission of $H$. atra would be variable among locations, and key factors 
of fission would not only be seasonal temperature or heat stress, but also include other factors such as low temperature stress, food availability and physical turbulence by waves or tides during the winter season.

The growth rate $(\mathrm{K})$ of $H$. atra estimated by the cohort analysis was 0.084 , which was comparable to previously reported growth of the same species (Ebert 1978) but at the lowest level among the growth of Aspidochirotida (Holothuriida and Synallactida) sea cucumbers (Shelley 1985, Conand 1989b, Poot-Salazar et al. 2014, Purcell et al. 2016b). Growth rate of $H$. atra has been reported to be an order-of-magnitude variable among environments (Chao et al. 1994; Lee et al. 2008); the growth observed in this study was ca $2 \mathrm{~cm}$ year $^{-1}$ for individuals of $12-15 \mathrm{~cm}$ long, corresponding to ca $3 \mathrm{~g} \mathrm{month}^{-1}$ calculated using a body length-weight equation (Conand 1989a), which was comparable to growth of $H$. atra as 3-6 g month ${ }^{-1}$ in Great Barrier Reef (Harriott 1982) and La Réunion (Conand 2004) as calculated by Lee et al. (2008). These growth can be regarded as low for this species, because this species can grow at $30 \mathrm{~g} \mathrm{month}^{-1}$ (Lee et al. 2008) or grow from $6 \mathrm{~g}$ to $324 \mathrm{~g}$ in 1.5 years (Chao et al. 1994) when environments are better. In the analysis, we assumed seasonal oscillation of growth, including shrinkage (degrowth), as these growth patterns have been reported for holothurians (Uthicke \& Benzie 2002, Uthicke et al. 2004). As a result, the estimated growth showed seasonal shrinkage during winter, which can partly explain the seasonal variation of body lengths described above. The combination of the low growth rate, winter shrinkage of body sizes, and saturated densities (Fig. 4a) suggests that the population density of $H$. atra was at the carrying capacity in this area and that the growth of individuals was limited by environmental resources (e.g., food availability). The estimated maximum body length of $37.3 \mathrm{~cm}$ was plausible as it ranged between reported values of $32 \mathrm{~cm}$ (Ebert 1978) and $60.0 \mathrm{~cm}$ (Bonham \& Held 1963). One $H$. atra individual over $40 \mathrm{~cm}$ long was observed on the deep bottom of the pool at the back reef of Yoshihara (Nishihama per. obs.).

\section{Relationship between growth plasticity and fission}

The low frequency of asexual fission in this study can be regarded as an exceptional case in populations of $H$. atra of small morphotypes living in shallow environments because most previous studies reported higher frequencies (up to $\sim 40 \%$ ) of asexual fission (Harriot 1982, Chao et al. 1993, Conand 1996, Uthicke 1997, 2001b, Thorne \& Byrne 2013). One of the potential roles of asexual fission is to achieve optimum individual size with respect to environmental conditions (Uthicke 2001b, Lee et al. 2008), whereby small body size can be beneficial to avoid dryness during low tide. However, in our case, growth plasticity was substituted in sustaining a small body size. Potential factors that promote asexual fission are high mortality, low habitat stability, small optimum individual size, high food availability and low larval supply (Uthicke 2001b). Among these factors, the population density was consistently high in this study, implying limited food availability. Such conditions may have inhibited $H$. atra from asexual fission (Lee et al. 2008). It has also been pointed out that some individuals after fission will die (Conand 1996); the mortality was $0 \%$ to $7.5 \%$ under laboratory conditions (Laxminarayana 2006). Therefore, asexual fission might be a risky strategy for an individual in a stable, climax population where mortality is normally low, because: (1) the environmental share of the individual is taken up by other individuals if the products die after fission; and (2) fission products cannot expect to gain enough resources to heal the fission wound and recover the body size unless other individuals die, if the environmental resources are already fully utilized. Considering these factors, regulating growth (including shrinkage) in response to environmental change would be safer than asexual fission. It is suggested that growth plasticity is a key factor, together with asexual reproduction, to support the dominance of this species in shallow reef environments.

\section{Implications for mechanisms and ecological meanings of sand-coating}

Because the sand-coated ratio of $H$. atra was positively correlated with wind speed (Table 2), we assumed that strong wind conditions increased the amount of suspended sand particles in the water column, which then attached to the skin of $H$. atra more frequently. On the other hand, there was no relationship between temporal variations in the sand cover ratio and temperature or irradiation. These results suggest that the sand-coated ratio of $H$. atra was determined by passive attachment rather than active collection of sand particles in response to environmental stresses such as high temperature or irradiation. In fact, there have been no observations that $H$. atra actively collects bottom sand on the dorsal side by rotating its body. Bonham \& Held (1963) discussed the ecological meaning of the sand-coating behavior as protection from high temperature, irradiation, or predators, but Bakus (1973) doubted that coating behavior was an adaptation to heat stress because many holothurians are bathed in seawater, at least in part. Although heat-tolerance was not directly tested here, it does not seem to have affected the survival of $H$. atra at least on a population scale because neither the densities or ratios of non-coated individuals decreased during summer seasons under high temperatures and strong irradiation. We could not find other trends such as spatial segregation between sand-coated and non-coated individuals, different seasonal patterns in distributions or size compositions between two types. Therefore, the ecological reasons why $H$. atra is coated with sand particles are still unresolved.

\section{Acknowledgements}

We thank Dr. Kei-ichi Mito and Ms. Masayo Ogura for 
field work and Ms. Satsuki Ohshiro for help formatting the data for the analysis. We would like to thank Editage (www.editage.com) for English language editing.

\section{References}

Akamine J (2004) The status of the sea cucumber fisheries and trade in Japan: past and present. In: Advances in Sea Cucumber Aquaculture and Management. FAO Fisheires Technical Paper No. 463 (eds Lovatelli A. Conand C, Purcell S, Uthicke S, Hamel J-F, Mercier A). FAO, Rome, pp. 39-47.

Akamine J (2015) Apostichopus japonicus: fisheries, trade, and foodways in Japan. In: The Sea Cucumber Apostichopus japonicus: History, Biology and Aquaculture (eds Yang HS, Hamel J-F, Mercier A). Academic Press, London, UK, pp. $399-421$.

Anderson SC, Flemming JM, Watson R, Lotze HK (2011) Serial exploitation of global sea cucumber fisheries. Fish Fish 12: 317-339.

Asha PS, Diwakar K, Santhanavalli G, Manissery M (2015) Comparative distribution and habitat preference of the sea cucumber Holothuria atra Jaeger at protected and unprotected sites in Thoothukudi region of Gulf of Mannar, south-east coast of India. Indian J Fish 62: 52-57.

Bakus GJ (1973) The biology and ecology of tropical holothurians. In: Biology and Geology of Coral Reefs Vol. II: Biology 1 (eds Jones OA, Endean B). Academic Press, New York, pp. 325-367.

Beverton RJ, Holt SJ (1956) A review of methods of estimating mortality rates in exploited fish populations, with special reference to sources of bias in catch sampling. Rapports et ProcèsVerbaux des RèunI ons Commission Internationale pour l'Exploration Scientifique de la Mer Méditerranée 140: 67-83.

Birkeland C (1988) The influence of echinoderms on coral reef communities. In: Echinoderm Studies Vol. 3 (eds Jangoux M, Lawrence JM). Balkema, Rotterdam, pp. 1-79.

Bonham K, Held EE (1963) Ecological observation on the sea cucumbers Holothuria atra and H. leucospilota at Rongelap Atoll, Marshall Islands. Pac Sci 17: 305-314.

Bourgoin A, Edward A (2005) Distribution, abundance and management of potential commercial holothurians in Pohnpei lagoon, Federated States of Micronesia. Micronesica 38: 47-66.

Bourjon P, Vasquez S (2016). Predation by the gastropod Tonna perdix (Gastropoda: Tonnoidea) on the holothurian Actinopyga echinites (Echinodermata: Holothuroidea) on a reef of Réunion. Bêche-de-mer Inf Bull 36: 45-47.

Chao SM, Chang KH (1989) The shallow-water holothurians (Echinodermata: Holothuroidea) of southern Taiwan. Bull Inst Zool Acad Sin 28: 107-137.

Chao SM, Chen CP, Alexander PS (1993) Fission and its effect on population structure of Holothuria atra (Echinodermata: Holothuroidea) in Taiwan. Mar Biol 116: 109-115.

Chao SM, Chen CP, Alexander PS (1994) Reproduction and growth of Holothuria atra (Echinodermata: Holothuroidea) at two contrasting sites in southern Taiwan. Mar Biol 119: $565-570$.

Choe S (1963) Biology of the Japanese Common Sea Cucum- ber Stichopus japonicus SELENKA. Kaibundo, Tokyo, pp. $\mathrm{X}+226+1$ Plate. (in Japanese with English summary and captions)

Conand C (1989a) Les Holothuries Aspidochirotes du lagon de Nouvelle-Calédonie: biologie, écologie et exploitation. $\mathrm{PhD}$ thesis. ORSTOM, Paris, France. (in French with English summary)

Conand C (1989b) Comparison between estimations of growth and mortality of two Stichopodid holothurians: Thelenota ananas and Stichopus chloronotus (Echinodermata: Holothuroidea). Proc 6th Int Coral Reef Symp pp. 661-665.

Conand C (1996) Asexual reproduction by fission in Holothuria atra: variability of some parameters in populations from the tropical Indo-Pacific. Oceanol Acta 19: 209-216.

Conand C (2004) Monitoring a fissiparous population of Holothuria atra on a fringing reef on Reunion Island (Indian Ocean). Bêche-de-mer Inf Bull 20: 22-25.

Conand C (2018) Tropical sea cucumber fisheries: changes during the last decade. Mar Pol Bull 133: 590-594.

Conand C, Byrne M (1993) A review of recent developments in the world sea cucumber fisheries. Mar Fish Rev 55: 1-13.

Dolmatov IY (2014) Asexual reproduction in holothurians. Sci World J 2014. Available at http://dx.doi.org/10.1155/2014/ 527234 (accessed on 27 November 2019)

Ebert, TA (1978) Growth and size of the tropical sea cucumber Holothuria (Halodeima) atra Jager at Enewetak atoll, Marshall Islands. Pac Sci 32: 183-191.

Eriksson H, Byrne M, de la Torre-Castro M (2012) Sea cucumber (Aspidochirotida) community, distribution and habitat utilization on the reefs of Mayotte, Western Indian Ocean. Mar Ecol Prog Ser 452: 159-170.

Francour P (1997). Predation on holothurians: a literature review. Inver Biol 116: 52-60.

Friedman K, Eriksson H, Tardy E, Pakoa, K (2011) Management of sea cucumber stocks: Patterns of vulnerability and recovery of sea cucumber stocks impacted by fishing. Fish Fish 12: 75-93.

Gittleman JL, Kot M (1990) Adaptation: statistics and a null model for estimating phylogenetic effects. Sys Zool 39: 227241.

Graham JCH, Battaglene SC (2004) Periodic movement and sheltering behaviour of Actinopyga mauritiana (Holothuroidea: Aspidochirotidae) in Solomon Islands. Bêch-de-mer Inf Bull 19: 23-31.

Hamel J-F, Eeckhaut I, Mercier A (2017). New host for the parasitic worm Anoploium sp. (Rhabditophora: Platyhelminthes) found in the sea cucumber Isostichopus fuscus (Holothuroidea: Echinodermata). Bêche-de-mer Inf Bull 37: 75-78.

Harriott V (1982) Sexual and asexual reproduction of Holothuria atra Jaeger at Heron Island Reef, Great Barrier Reef. Aust Mus Mem 16: 53-66.

Hasan MH (2005) Destruction of a Holothuria scabra population by overfishing at Abu Rhamada Island in the Red Sea. Mar Env Res 60: 489-511.

Hasan MH (2019) Destruction of sea cucumber populations due to overfishing at Abu Ghosoun area, Red Sea. J Basic Applied Zool 80: 5 .

Imaoka T (1995) Holothuroidea. In: Guide to Seashore Animals 
of Japan with Color Pictures and Keys Vol. II (ed Nishimura S). Hoikusha, Ohsaka, pp. 553-572. (In Japanese)

Koike H, Usseglio P, Ramos F (2015) Baseline assessment of virgin biomass of sea cucumbers in Old Providence and Santa Catalina, Western Caribbean. Bêche-de-mer Inf Bull 15: 42 49.

Komala R, Miarsyah M, Wulaningsih RD (2019) Holothuroidea as a constituent of benthic communities in the seagrass ecosystems at Bira Island Islands. IOP Conf Ser: Earth Env Sci 391. 012046.

Lampe K (2013) Holothurian density, distribution and diversity comparing sites with different degrees of exploitation in the shallow lagoons of Mauritius. Bêche-de-mer Inf Bull 33: 23 29.

Lampe-Ramdoo K, Pillay RM, Conand C (2014) An assessment of holothurian diversity, abundance and distribution in the shallow lagoons of Mauritius. Bêche-de-mer Inf Bull 34: $17-24$.

Laxminarayana A (2006) Asexual reproduction by induced transverse fission in the sea cucumbers Bohadschia marmorata and Holothuria atra. Bêche-de-mer Inf Bull 23: 35-37.

Lee J, Byrne M, Uthicke S (2008) The influence of population density on fission and growth of Holothuria atra in natural mesocosms. J Exp Mar Biol Ecol 365: 126-135.

Massin C, Doumen C (1986) Distribution and feeding of epibenthic holothuroids on the reef flat of Laing Island (Papua New Guinea). Mar Ecol Prog Ser 31: 185-195.

Mildenberger TK, Taylor MH, Wolff M (2017) TropFishR: an $\mathrm{R}$ package for fisheries analysis with length-frequency data. Methods Ecol Evol 8: 1520-1527.

Mitsukuri K (1912) Studies on Actinopodous Holothurioidea. J Col Sci, Impe Uni Tokyo 39: 1-284. Pls 1-8.

Moriarty DJW (1982) Feeding of Holothuria atra and Stichopus chloronotus on bacteria, organic carbon and organic nitrogen in sediments of the Great Barrier Reef. Aust J Mar Freshw Res 33: 255-263.

Mueller KW (2017) Symbionts of the giant red sea cucumber, Parastichopus californicus (Stimpson, 1857), with some implications for culture of the host. Bêche-de-mer Inf Bull 37: 79-91.

Nishihira M, Shingaki N, Motonaga T (1978) Intertidal population of Polycheira rufescens (Brandt) (Chiridatoidae: Holothurioidea) in Okinawa-preliminary observations. Benthos Res 15/16: 73-86. (in Japanese)

Ohshima H (1935) Commercial holothurians in Ryukyu. Bulteno Scienca de la Fakultato Terkultura, Kjusu Imperia Universitato 6: 139-155. (in Japanese with Esperanto resume)

Paradis E (2019) Package 'ape' Ver. 5.3: Analyses of Phylogenetics and Evolution. Available at http://ape-package.ird.fr/ (accessed on 17 June 2021)

Poot-Salazar A, Hernández-Flores Á, Ardisson P-L (2014) Use of the SLW index to calculate growth function in the sea cucumber Isostichopus badionotus. Sci Rep 4: 5151.

Purcell SW, Conand C, Uthicke S, Byrne M (2016a) Ecological roles of exploited sea cucumbers. Oceangr Mar Biol, Ann Rev. 54: 367-386.

Purcell SW, Mercier A, Conand C, Hamel JF, Toral-Granda MV, Lovatelli A, Uthicke S. (2013) Sea cucumber fisheries: global analysis of stocks, management measures and drivers of overfishing. Fish Fish 14: 34-59.

Purcell S, Piddocke T, Dalton S, Wang Y (2016b) Movement and growth of the coral reef holothuroids Bohadschia argus and Thelenota ananas. Mar Ecol Prog Ser 551: 201-214.

Purcell SW, Samyn Y, Conand C (2012) Commercially Important Sea Cucumbers of the World. FAO Species Catalogue for Fishery Purposes No. 6. FAO, Rome, viii+pp.150+30 Plates.

Purwati P, Dwiono SAP, Indriana LF, Fahmi V (2009) Shifting the natural fission plane of Holothuria atra (Aspidochirotida, Holothuroidea, Echinodermata). Bêche-de-mer Inf Bull 29: 16-19.

$\mathrm{R}$ developing core team (2019) $\mathrm{R}$ version 3.6.2: a language and environment for statistical computing. Vienna, Austria: $\mathrm{R}$ foundation for statistical computing. Available at https:// www.R-project.org/ (accessed on 16 March 2020)

Roff J, Zacharias M (2011) Marine Conservation Ecology. Earthscan, London. $\mathrm{xx}+439 \mathrm{pp}$.

Schneider G, Chicken E, Becvarik R (2018) Package 'NSM3': functions and datasets to accompany Hollander, Wolfe, and Chicken-Nonparametric Statistical Methods, third edition. Available at https://cran.r-project.org/web/packages/NSM3/ NSM3.pdf (accessed on 17 June 2021)

Setyastuti A, Dharmawan IWE, Hafiz M, Vimono IB, Aji LP (2018) Discovery of Holothuria leucospilota juveniles on Pai Island, Biak-Papua, and an overview of sea cucumber nursery grounds in Indonesia. Bêche-de-mer Inf Bull 38: 29-36.

Shelley C (1985) Growth of Actinopyga echinites and Holothuria scabra (Holothurioidea: Echinodermata) and their fisheries potential (as beche-de-mer) in Papua New Guinea. Proc Fifth Int Coral Reef Congr pp. 297-302.

Susetya IE, Wahyuni S, Fadhilah A, Harahap ZA, Yusni E, Saridu SA (2019) Community structure of echinoderms in seagrass ecosystem of Pandaratan Beach, Tapanuli Tengah Regency, North Sumatera. IOP Conf Ser Earth Env Sci 260: 012107.

Tanita I, Yamada H (2019) Distribution of sea cucumbers in relation to sediment characteristics in coral reef lagoons and adjacent waters around Ishigaki Island, southern Japan. Mar Ecol 40. e12564.

Toral-Granda V, Lovatelli A, Vasconcellos M. (eds.) (2008) Sea Cucumbers, A Global Review of Fisheries and Trade. FAO, Fisheries and Aquaculture Technical Paper. No. 516. FAO, Rome. 317 p.

Thorne BV, Byrne M (2013) Survivorship of post-split fission products of Holothuria atra (Holothuroidea: Aspidochirotida) on the southern Great Barrier Reef. Inver Reprod Dev 57: 293300 .

Thorne BV, Eriksson H, Byrne M (2013) Long term trends in population dynamics and reproduction in Holothuria atra (Aspidochirotida) in the southern Great Barrier Reef; the importance of asexual and sexual reproduction. J Mar Biol Ass UK 93: 1067-1072.

Uehara M (1991) Sea Cucumbers. In: Aquaculture in Tropical Areas (eds Shokita S, Kakazu K, Tomori A, Toma T, Yamaguchi M). Midori-shobo, Tokyo, pp. 306-313.

Uthicke S (1994) Distribution patterns and growth of two reef flat holothurians Holothuria atra and Stichopus chloronotus. 
In: Echinoderm through Time (eds David B, Guille A, Feral J-P). Balkema, Rotteldam, pp. 569-576.

Uthicke S (1997) Seasonality of asexual reproduction in Holothuria (Halodeima) atra, H. (H.) edulis and Stichopus chloronotus (Holothuroidea: Aspidochirotida) on the Great Barrier Reef. Mar Biol 129: 435-441.

Uthicke S (1999) Sediment bioturbation and impact of feeding activity of Holothuria atra and Stichopus chloronotus, two sediment feeding holothurians at Lizard Island, Great Barrier Reef. Bull Mar Sci 64: 129-141.

Uthicke S (2001a) Interactions between sediment-feeders and microalgae on coral reefs: grazing losses versus production enhancement. Mar Ecol Prog Ser 210: 125-138.

Uthicke S (2001b) Influence of asexual reproduction on the structure and dynamics of Holothuria (Halodeima) atra and Stichopus chloronotus populations of the Great Barrier Reef. Mar Freshw Res 52: 205-215.

Uthicke S, Benzie JAH, Ballment E (1998) Genetic structure of fissiparous populations of Holothuria (Halodeima) atra on the Great Barrier Reef. Mar Biol 132: 141-151.

Uthicke S, Karez R (1999) Sediment patch selectivity in tropical sea cucumbers (Holothurioidea: Aspidochirotida) analysed with multiple choice experiments. J Exp Mar Biol Ecol 236: 69-87.
Uthicke S, Benzie JAH (2002) A genetic fingerprint recapture technique for measuring growth in "unmarkable" invertebrates: negative growth in commercially fished holothurians (Holothuria nobilis). Mar Ecol Prog Ser 241: 221-226.

Uthicke S, Welch D, Benzie JAH (2004) Slow growth and lack of recovery in overfished holothurians on the Great Barrier Reef: evidence from DNA fingerprints and repeated large-scale surveys. Conserv Biol 18: 1395-1404.

Wada K (1992) Temporal change in density and size structure of the sea cucumber Polycheira rufescens inhabiting the intertidal boulder beach at Hatakejima Island, Tanabe Bay, central Japan. Publ Seto Mar Biol Lab 35: 363-370.

Wakabayashi M, Wada K (2010) Cross-shore distribution and life history of the sea cucumber Patinapta ooplax inhabiting an intertidal sand flat. Jpn J Benthol 65: 2-5. (in Japanese with English title, abstract and captions)

Webb KL, D'Elia CF, Dupaul WD (1977) Biomass and nutrition flux measurements on Holothuria atra populations on windword reef flats at Enewetak, Marshall Islands. Proc Third Int Coral Reef Symp pp. 409-415.

Yamana Y, Kinoshita T, Obuchi M, Fujii T (2020) A preliminary evaluation of the distribution pattern of sea cucumbers in the semi-closed waters of the Amami Islands. Plankton Benthos Res 15: 168-177. 


\section{Appendix}

$1997 / 4 / 24$

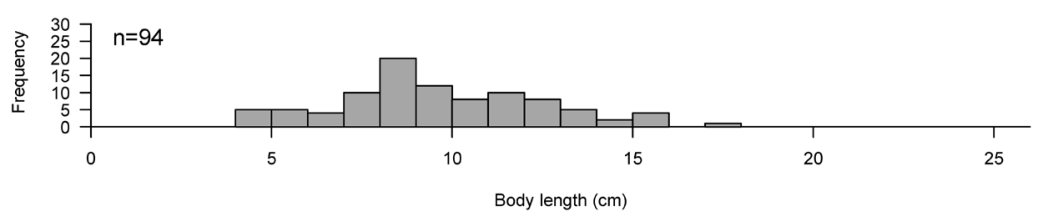

$1997 / 6 / 5$

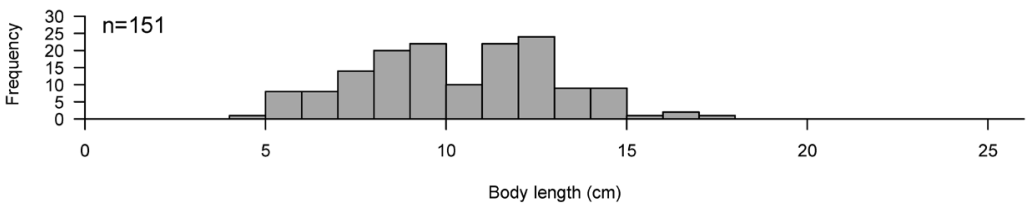

$1997 / 8 / 21$

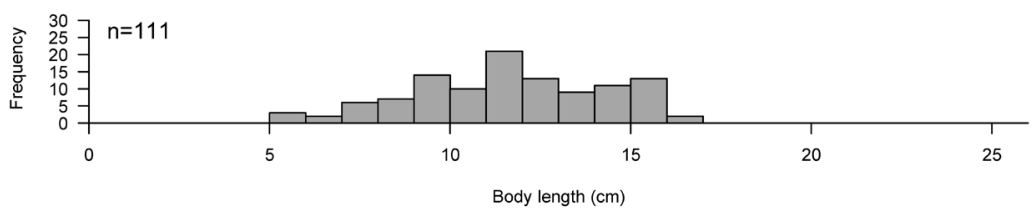

1997/11/11

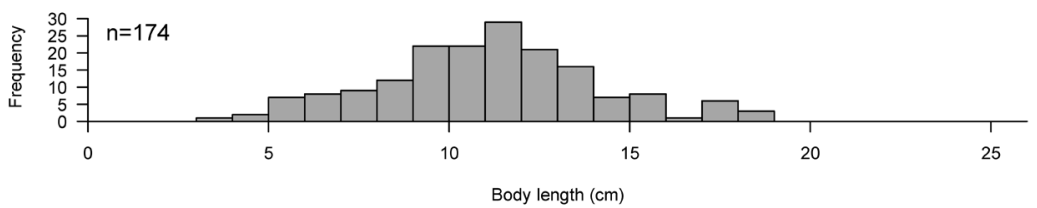

$1998 / 1 / 30$
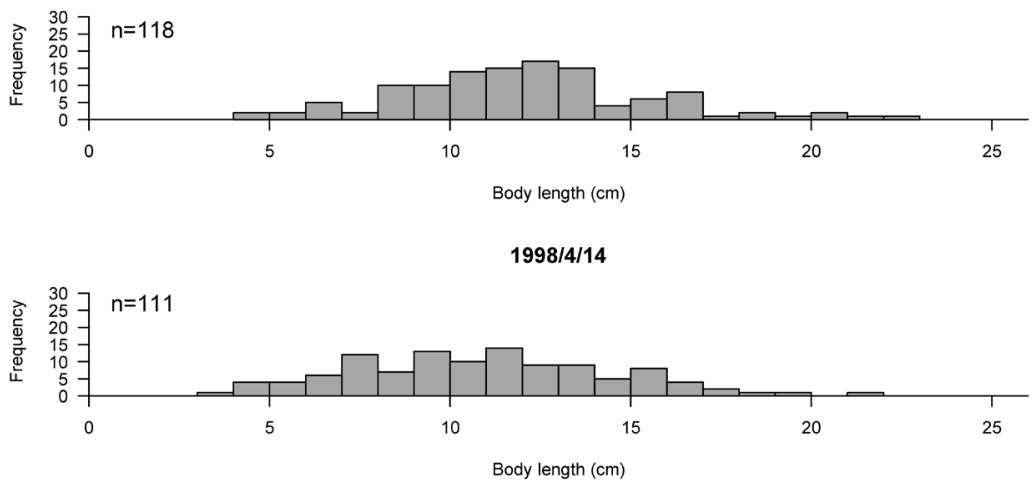

$1998 / 6 / 25$

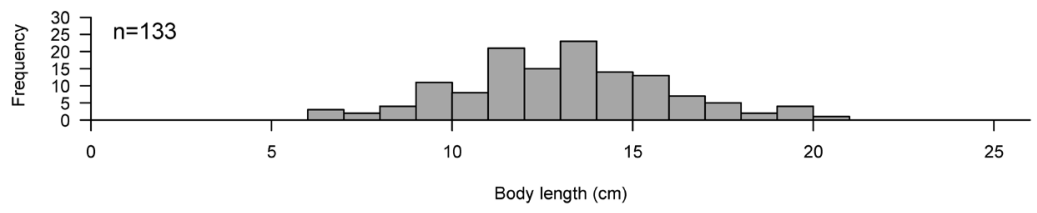

$1998 / 8 / 21$

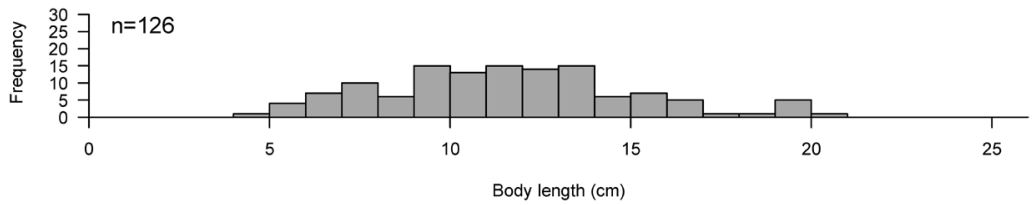



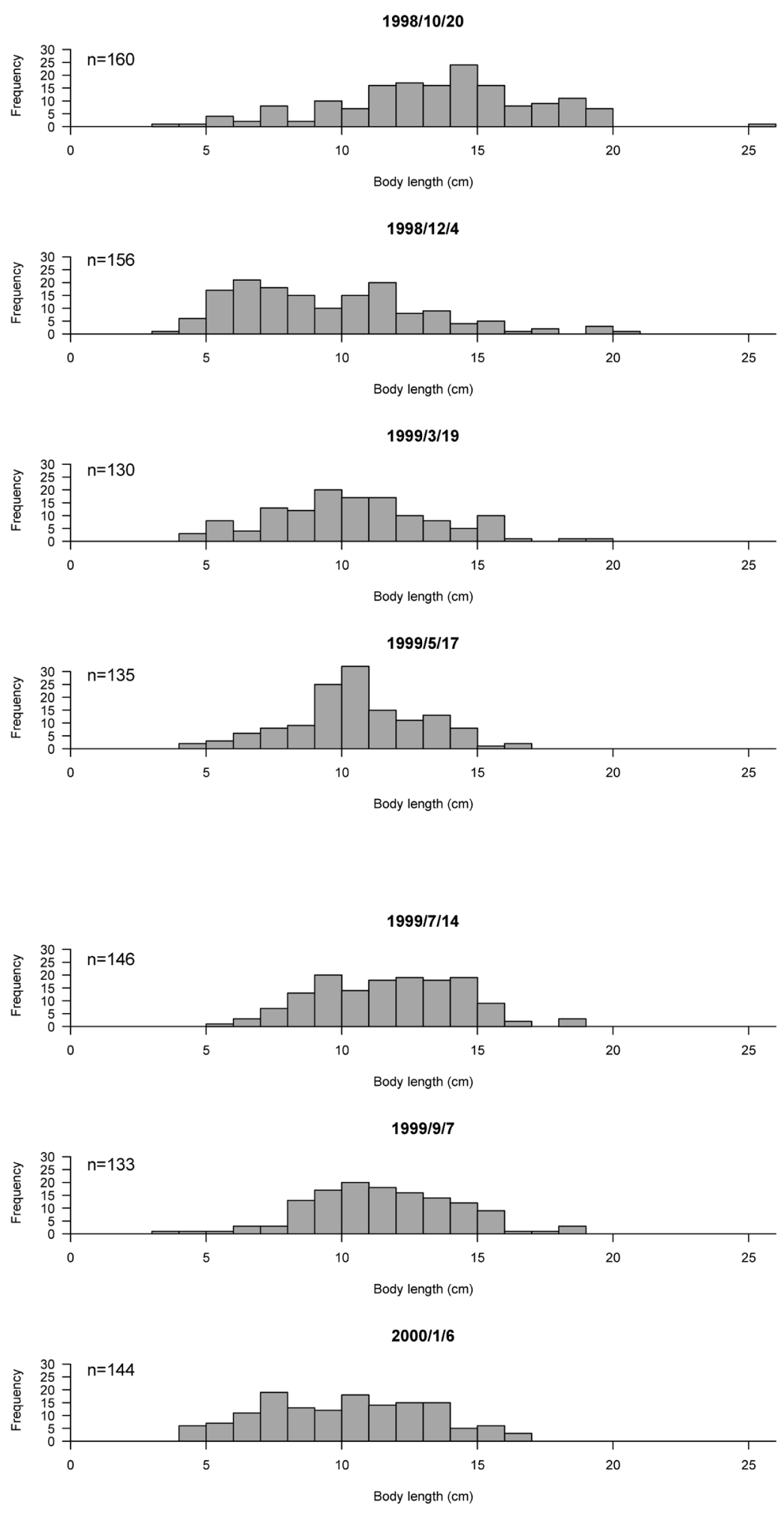

2000/3/7

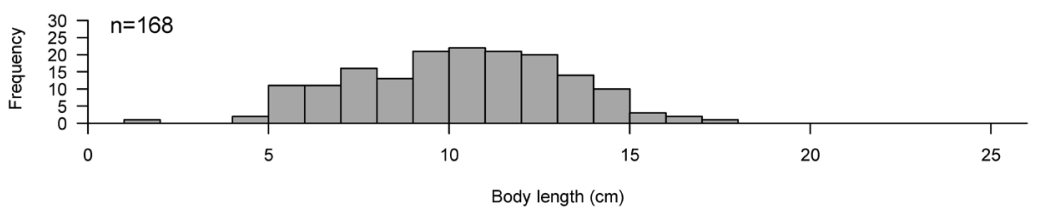

Fig. A1. Length-frequency size histograms of Holothuria atra and its seasonal variation on a seagrass-dominated reef flat at Yoshihara. 